\title{
Frontières
}

\section{Bibliographie indicative sur la résilience et le deuil}

Volume 22, numéro 1-2, automne-printemps 2009-2010

Résilience et deuil

URI : https://id.erudit.org/iderudit/045047ar

DOI : https://doi.org/10.7202/045047ar

Aller au sommaire du numéro

Éditeur(s)

Université du Québec à Montréal

ISSN

1180-3479 (imprimé)

1916-0976 (numérique)

Découvrir la revue

Citer ce document

(2009). Bibliographie indicative sur la résilience et le deuil. Frontières, 22(1-2),

135-136. https://doi.org/10.7202/045047ar d'utilisation que vous pouvez consulter en ligne.

https://apropos.erudit.org/fr/usagers/politique-dutilisation/ 


\section{BIBLIOGRAPHIE INDICATIVE SUR LA RÉSILIENCE ET LE DEUIL}

AHERN, N.R. (2006). «Adolescent resilience: An evolutionary concept analysis ", Journal of Pediatric Nursing, vol. 21, $n^{\circ} 3$, p. 175-185.

ANAUT, M. (2004). "La résilience en situations de soins: approche théorico-clinique », Recherche en soins infirmiers, vol. 77, p. 9-19.

ANAUT, M. (2005). «Le concept de résilience et ses applications cliniques", Recherche en soins infirmiers, vol. 82, p. 4-10.

ANAUT, M. (2006). La résilience, Surmonter les traumatismes, Paris, Armand Colin.

BENIGHT, C.C. et A. BANDURA (2004). "Social cognitive theory of posttraumatic recovery: The role of perceived self-efficacy ", Behaviour Research and Therapy, vol. 42, p. 1129-1148.

BLACK, K. et M. LOBO (2008). «A conceptual review of family resilience factors ", Journal of Family Nursing, vol. 14, nº 1, p. 33-55.

BROWN-BAATJIES, O., P. FOUCHE et al. (2008). "The development and relevance of the Resiliency model of family stress, adjustment and adaptation ", Acta Academica, vol. 40, n 1, p. 78-126.

CAMPBELL-SILLS, L. et M.B. STEIN (2007). "Psychometric analysis and refinement of the Connor-Davidson Resilience Scale (CD-RISC): Validation of a 10 -item measure of resilience ", Journal of Traumatic Stress, vol. 20, n 6 , p. 1019-1028.

CHAN, C.L.W., T.H.Y. CHAN et al. (2006). "The Strength-Focused and Meaning-Oriented Approach to Resilience and Transformation (SMART): A body-mind-spirit approach to trauma management", Social Work in Health Care, vol. 43, n²-3, p. 9-36.

CONNOR, K.M. (2006). «Assessment of resilience in the aftermath of trauma ", Journal of Clinical Psychology, vol. 67, suppl. 2, p. 46-49.

CONNOR, K.M. et J.R.T. DAVIDSON (2003). «Development of a new resilience scale: The Connor-Davidson Resilience Scale (CD-RISC) ", Depression and Anxiety, vol. 18, p. 76-82.

CYRULNICK, B. (1999). Un merveilleux malheur, Paris, Odile Jacob.

DAYER-MÉTROZ, M.-D. (2002). «La résilience: un concept qui ouvre de nouvelles perspectives dans l'accompagnement à long terme des patients", Revue médicale de la Suisse romande, vol. 122, p. 245-247.

DELAGE, M. (2002). «Aide à la résilience familiale dans les situations traumatiques», Thérapie familiale, vol. 23, n³, p. 269-287.

DELAGE, M. (2008). La résilience familiale, Paris, Odile Jacob.

DEROON-CASSINI, T.A., A.D. MANCINI et al. (2010). "Psychopathology and resilience following traumatic injury: A latent growth mixture model analysis", Rehabilitation Psychology, vol. $55, n^{\circ} 1$, p. 1-11.
DUMONT, C., M. GERVAIS et al. (2004). «Toward an explanatory model of social participation for adults with traumatic brain injury", Journal of Head Trauma Rehabilitation, vol. 19, $n^{\circ} 6$, p. 431-444.

DYER, J.G. et T. M. MCGUINNESS (1996). "Resilience: Analysis of the concept ", Archives of Psychiatric Nursing, vol. 10, $\mathrm{n}^{\circ} 5$, p. 276-282.

EARVOLINO-RAMIREZ, M. (2007). «Resilience: A concept analysis», Nursing Forum, vol. 42, n ${ }^{\circ} 2$, p. 73-82.

FREEDMAN, R. (2008). "Coping, resilience, and outcome ", American Journal of Psychiatry, vol. $165, n^{\circ} 12$, p. 1505-1506.

GILLEPSIE, B.M., W. CHABOYER et al. (2007). «Development of a theoretically derived model of resilience through concept analysis ", Contemporary Nurse, vol. 25, nos 1-2, p. 124-135.

GLANTZ, M.D. et Z. SLOBODA (1999). "Analysis and reconceptualization of resilience», dans M.D. GLANTZ et J.L. JOHNSON (dir.), Resilience and Development: Positive Life Adaptations, New York, Kluwer Academic/Plenum Publishers, p. 109-126.

HARNEY, P. (2007). «Resilience processes in context», Journal of Aggression, Maltreatment and Trauma, vol. 14, ${ }^{\circ} 3$, p. 73-87.

JOURDAN-IONESCU, C. (2001). «Intervention écosystémique individualisée axée sur la résilience », Revue québécoise de psychologie, vol. 22, $n^{\circ} 1$, p. 163-186.

KING, G., T. CATHERS et al. (2003). "Turning points and protective processes in the lives of people with chronic disabilities ", Qualitative Health Research, vol. 13, n², p. 184-206.

KUMPFER, K.L. (1999). " Factors and processes contributing to resilience: The resilience framework », dans M.D. GLANTZ et J.L. JOHNSON (dir.), Resilience and Development: Positive Life Adaptations, New York, Kluwer Academic/Plenum Publishers, p. 179-224.

LANDAU, J. (2007). «Enhancing resilience: Families and communities as agents for change " Family Process, vol. 46, n 3, p. 351-365.

LECOMTE, J. (2002). «Qu'est-ce que la résilience? Question faussement simple. Réponse nécessairement complexe ", Pratiques psychologiques, vol. 1, p. 7-14.

LEFEBVRE, H. et M.J. LEVERT (2005). «Traumatisme craniocérébral: de la souffrance à la résilience», Frontières, vol. 17, n 2 , p. 77-85.

LUTHAR, S.S., D. CICCHETTI et al. (2000). "The construct of resilience: A critical evaluation and guidelines for future work ", Child Development, vol. 71, nº 3, p. 543-562.

MANCINI, A.D. et G.A. BONANNO (2006). «Resilience in the face of potential trauma: Clinical practices and illustrations ", Journal of Clinical Psychology, vol. 62, nº 8, p. 971-985.

MCCUBBIN, L. (2001). Challenges to the Definition of Resilience, San Francisco, American Psychological Association Conference.

MONAGHAN-BLOUT, S. (1996). «Re-examining assumptions about trauma and resilience: Implications for intervention ", Psychotherapy in Private Practice, vol. $15, n^{\circ}$ 4, p. 45-69.
NYGREN, B., L. ALÉX et al. (2005). «Resilience, sense of coherence, purpose in life and self-transcendence in relation to perceived physical and mental health among the oldest old ", Aging and Mental Health, vol. $9 n^{\circ} 4$, p. 354-362.

ONG, A.D., C.S. BERGEMAN et al. (2009). "Resilience comes of age: Defining features in later adulthood ", Journal of Personality, vol. 77, $n^{\circ} 6$, p. 1777-1804.

PATTERSON, J.M. (2002). « Understanding family resilience ", Journal of Clinical Psychology, vol. 58, $n^{\circ} 3$, p. 233-246.

PHILLIPS, G. (2008). «Resilience in practice interventions», Child Care in Practice, vol. 14, n 1, p. 45-54.

QUALE, A. et A.-K. SCHANKE (2010). «Resilience in the face of coping with a severe physical injury: A study of trajectories of adjustment in a rehabilitation setting ", Rehabilitation Psychology, vol. 55, n 1, p. 12-22.

RICHARDSON, G.E. (2002). "The metatheory of resilience and resiliency ", Journal of Clinical Psychology, vol. 58, n³, p. 307-321.

RICHARDSON, G.E., B.L. NEIGER, S. JENSEN et K.L. KUMPFER (1990). "The resiliency model», Health Education, vol. 21, p. 33-39.

ROGERSON, M. et C. EMES (2008). «Fostering resilience within an adult day support program ", Activities, Adaptation and Aging, vol. 32, $\mathrm{n}^{\circ} 1$, p. 1-18.

ROOSA, M. (2000). «Some thoughts about resilience versus positive development, main effects versus interactions, and the value of resilience", Child Development, vol. 71, n³, p. 567-569.

ROUSSEAU, S. (2010). Développer et renforcer sa résilience, Vivre heureux même si..., Montréal, Éditions Québécor.

RUTTER, M. (1993). «Resilience: Some conceptual considerations", Journal of Adolescent Health, vol. $14, n^{\circ} 8$, p. 626-631.

SILLIMAN, B. (1998). «The resiliency paradigm: $A$ critical tool for practitioners», Human Development and Family Life Bulletin, vol. 4, n 1, p. 4-5.

SIMON, J.B., J.J. MURPHY et al. (2005). "Understanding and fostering resilience ", The Family Journal: Counseling and Therapy for Couples and Families, vol. $13, \mathrm{n}^{\circ} 4$, p. 427-436.

STEINHARDT, M. et C. DOLBIER (2008). «Evaluation of a resilience intervention to enhance coping strategies and protective factors and decrease symptomatology ", Journal of American College Health, vol. 56, n 4 , p. 445-453.

TISSERON, S. (2007). La résilience, Paris, Presses universitaires de France, coll. "Que sais-je?».

TUSSAIE, K. et K. PATTERSON (2006). «Relationships among trait, situational, and comparative optimism: Clarifying concepts for a theoretically consistent and evidence-based intervention to maximize resilience ", Archives of Psychiatric Nursing, vol. 20, n 3, p. 144-150.

WALSH, F. (1996). "The concept of family resilience: Crisis and challenge», Family Process, vol. 35, n³, p. 261-281.

WALSH, F. (2002). "A family resilience framework: Innovative practice applications », Family relations, vol. 51, n² 2, p. 130-137. 
WALSH, F. (2003). «Family resilience: A framework for clinical practice », Family Process, vol. 42, $\mathrm{n}^{\circ} 1$, p. 1-18

WERNER, E.E. et J.L. JOHNSON (1999). «Can we apply resilience?", dans M.D. GLANTZ et J.L. JOHNSON (dir.), Resilience and Development: Positive Life Adaptations, New York, Kluwer Academic/Plenum Publishers, p. 259-268.

WHITE, B., S. DRIVER et al. (2008). «Considering resilience in the rehabilitation of people with traumatic disabilities", Rehabilitation Psychology, vol. 53, n 1, p. 9-17.

WHITE, B., S. DRIVER et al. (2010). «Resilience and indicators of adjustment during rehabilitation from a spinal cord injury ", Rehabilitation Psychology, vol. 55, $n^{\circ} 1$, p. 23-32.

WILKES, G. (2002). «Introduction: A second generation of resilience research ", Journal of Clinical Psychology, vol. 58, n³, p. 229-232.

\section{NOUVELLES PARUTIONS- ÉTUDES SUR LA MORT}

Serge Gariépy,

bibliothécaire de référence,

Bibliothèque centrale, UQAM.

BEYANT, Clifton D. et Dennis L. PECK (2009). Encyclopedia of Death and Human Experience, Thousand Oaks, CA, Sage Publications.

BRENNAN, Samantha (2009). Philosophy and Death: Introduction Reading, Londres, Broadview Press.

CLAVANDIER, Gaëlle (2009). Sociologie de la mort, Vivre et mourir dans la société contemporaine, Paris, Armand Colin.

DEITS, Bob (2009). Revivre après l'épreuve, Montréal, Québécor.

FONTANA, Andrea (2009). Death and Dying in America, Cambridge, Polity.

HIRSCH, Emmanuel (2009). Face aux fins de vie et à la mort: éthique, société, pratiques professionnelles, Paris, Vuibert.
KESSLER, David et Elisabeth KÜBLER-ROSS (2009). Sur le chagrin et le deuil: trouver un sens à sa peine à travers les cinq étapes du deuil, Paris, JC Lattès.

LÉVY, Isabelle (2009). Les soignants face au décès: pour une meilleure prise en charge du défunt Paris, Estem.

MARTIN, Philippe (2007). Figures de la mort en Lorraine XVI-XIX siècle, Metz, Éditions Serpenoise.

PROULX, Mario (2010). Vivre jusqu'au bout, Montréal, Bayard.

REBILLARD, Eric (2009). The Care of the Dead in Late Antiquity, Ithaca, Cornell University Press.

RIVET, Daniel et Françoise RIVET (2009). Tu nous as quittés, Paraître et disparaître dans le carnet du Monde, Paris, Armand Colin.

SAINT VICTOR, Gabriel de (2008). La mort apprivoisée: message d'espoir de ceux qui partent à ceux qui restent, Paris, Presses de la renaissance.

TILLIER, Anne-Marie (2009). L'homme et la mort, Paris, CNRS.

ZERBIB, Marc (2009). La mort du père dans le travail social, Paris, ASH.

\section{ans
d'excellence
$2000-2010$}

La mission du CRIR est de contribuer à l'autonomie et à l'intégration sociale des personnes ayant une déficience physique (motrice, visuelle, auditive, parole et langage) par la recherche dans les domaines biomédical et psychosocial.
Le $\boldsymbol{C R I R}$, un centre de recherche opéré par l'association de six établissements de réadaptation, regroupe près de 65 chercheurs réguliers, 24 chercheurs associés, 88 membres cliniciens/intervenants et 300 étudiants aux cycles supérieurs.

\section{Axes et thématiques de recherche :}

- Fonctions et activités sensorielles, motrices et cognitives

$\rightarrow$ Mécanismes fonctionnels

- Activités physiques et cognitives

- Participation, inclusion sociale et services de réadaptation

४ Relations interpersonnelles et soutien, domaines de vie, vie communautaire, sociale et civique $\uparrow$ Services, systèmes et politiques

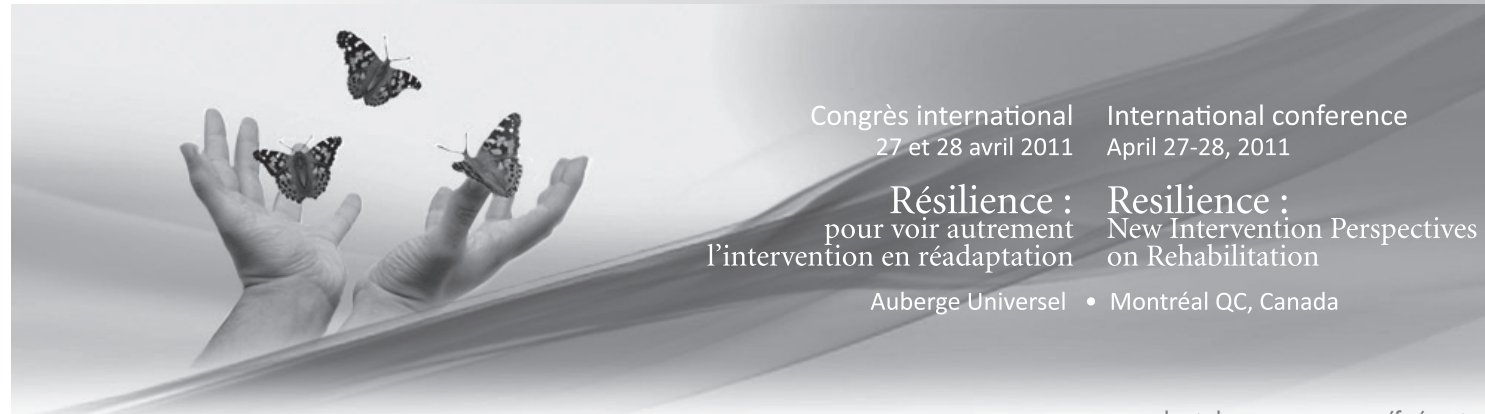

www.luciebruneau.qc.ca/fr/main_nav/calendrier/colloque-resilience 